\title{
REGULARARTICLE
}

\section{RESPONSE OF AN IDEOTYPE OF CLUSTER ONION (ALLIUM CEPA L. VAR. AGGREGATUM) TO FARM AND ANIMAL WASTES

\author{
D. ANBARASI* ${ }^{*}$ K. HARIPRIYA, C.T. SATHAPPAN, D. STELLA
}

Department of Horticulture, Faculty of Agriculture, Annamalai University, Annamalai Nagar 608 o02, Tamil Nadu, India

\begin{abstract}
In Tamilnadu, Ariyalur district contributes a major share of cluster onion production. An ideotype popular among the growers of this locality is preferred by consumers of entire state for its size, storability and taste. Hence the present investigation was carried out the in a farmer's field at Vennallur located in Ariyalur District during 2017. The experiment was laid out with seven treatments in randomized block design. Each treatment was replicated thrice. The treatments included three kinds of practices adopted by the farmers of the tract and four others where bulky organic manures (Vermicompost, Poultry manure) and concentrated organic manures (Neem cake and Groundnut cake) were substituted on ' $\mathrm{N}$ ' equivalent basis, along with biofertilizers (Azospirillum and Phosphobacteria) and foliar spray of Panchakavya (3\%). All the four treatments with organic inputs $\left(\mathrm{T}_{4}\right.$ to $\left.\mathrm{T}_{7}\right)$ gave better results, when compared to farmer's practice $\left(\mathrm{T}_{1}\right.$ and $\left.\mathrm{T}_{2}\right)$. Though $\mathrm{T}_{3}$ was the best, incorporation of Poultry manure+Neem cake $\left(\mathrm{T}_{6}\right)$ and Poultry manure+Groundnut cake $\left(\mathrm{T}_{7}\right)$ along with Biofertilizer+Panchakavya $3 \%$ improved the yield significantly in order.
\end{abstract}

Keywords: Onion, Organic cultivation, manure

\section{INTRODUCTION}

Cluster onion (Allium cepa L. Var. aggregatum, $2 \mathrm{n}=2 \mathrm{x}$ $=16$, family: Alliaceae) is one among the important vegetable crops cultivated in India. In India, it is grown in an area of 8.34 lakh hectares with an annual production of 135.65 lakh tonnes [1]. India ranks second in the world after China by contributing 12.30 per cent to the world production. It is semi-perishable in nature and can be transported to a long distance without much injury. India exports onion to countries like Malaysia, Russia, Kuwait, SriLanka, Singapore, Germany, Japan, Iran, Myanmar and U. K. [2].

There are many issues related to the cultivation and production of onion in India, like nutritional disorders. The continuous and imbalanced use of chemical fertilizers is adversely affecting the agricultural production [3]. Organically produced crops possess better biochemical and physical quality in onion without much compromise on yield statistics [4]. So the present study was designed to investigate the effect of organic manures on the growth and yield of aggregate onion.

\section{MATERIALS AND METHODS}

A field experiment entitled "Response of an ideotype of cluster onion (Allium cepa L. Var. aggregatum) to farm and animal remains" was conducted in a farmer's field at Venanallur located in Ariyalur District during the year 2017.
The experimental field is situated at $10^{\circ} \cdot 53^{\prime}-11^{\circ} .26^{\prime}$ North latitude; $78^{\circ} \cdot 56^{\prime}-79^{\circ} .31^{\prime}$ East longitude. The area usually receives annual rainfall of $440.4 \mathrm{~mm}$, average maximum temperature of $34^{\circ} \mathrm{C}$, average minimum temperature of $21^{\circ} \mathrm{C}$ and $46 \%$ Relative humidity. Texture of soil is sandy loam having $7.1 \mathrm{pH}$ and $660 \mu \mathrm{mho} / \mathrm{cm}$ EC. Seed bulbs of locally grown ideotype were used for cultivation. Schedule of treatments include $\mathrm{T}_{1}-\mathrm{FYM} 25 \mathrm{t} / \mathrm{ha} \rightarrow$ Farmer's practice 1 , $\mathrm{T}_{2}$-FYM $20 \mathrm{t} /$ ha+Azotobacter+PSB $\rightarrow$ Farmer's practice 2, $\mathrm{T}_{3}$-FYM 20t/ha+NPK 60:60: $30 \mathrm{~kg} / \mathrm{ha}+\mathrm{ZnSo}_{4}(0.5 \%) \rightarrow$ Farmer's practice $3, \mathrm{~T}_{4}-$ Vermicompost (1.8t/ha), Neem cake (0.57t/ha)+Azospirillum and Phospobacteria each @ 2 $\mathrm{kg} /$ ha+Panchakavya 3\%, $\mathrm{T}_{5}$-Vermicompost (1.8 t/ha), Groundnut cake (3 t/ha)+Azospirillum and Phospobacteria each @ $2 \mathrm{~kg} /$ ha+Panchakavya $3 \%$. T6-Poultry manure (o.6 t/ha), Neemcake (0.57 t/ha)+Azospirillum and Phospobacteria each @ $2 \mathrm{~kg} / \mathrm{ha}+$ Panchakavya 3\%, $\mathrm{T}_{7}-$ Poultry manure (0.6 t/ha),Groundnut cake (3 t/ha)+Azospirillum and Phospobacteria each @ 2 $\mathrm{kg} / \mathrm{ha}+$ Panchakavya $3 \%$. Bulbs were planted along the sides of ridges at $20 \times 12 \mathrm{~cm}$ spacing.

The organic manures-Vermicompost, Neem cake and Groundnut cake were applied in quantities calculated on 'N' equivalent basis. This experiment was laid out following randomized block design with the above seven treatments each of which was replicated thrice.

The field was well ploughed. FYM, Vermicompost, Poultry

\section{Received 21 March 2018; Accepted 30 April 2018 \\ *Corresponding Author \\ D. Anbarasi}

Department of Horticulture, Faculty of Agriculture, Annamalai University, Annamalai Nagar 608 o02, Tamil Nadu, India

Email: anbarasidevar@gmail.com

(CThis article is open access and licensed under the terms of the Creative Commons Attribution License (http://creativecommons.org/licenses/by/4.o/) which permits unrestricted, use, distribution and reproduction in any medium, or format for any purpose, even commercially provided the work is properly cited. Attribution - You must give appropriate credit, provide a link to the license, and indicate if changes were made. 
manure whole of $\mathrm{P}$ and $\mathrm{K}, 50 \%$ of $\mathrm{N}$ in $\mathrm{T}_{3}$ were incorporated during last ploughing in respective plots. Panchakavya (3\%) was sprayed twice during 45 and 60 DAP. In treatments involving Biofertilizer (Azospirillum and Phospobacteria), they were incorporated in soil each @ $2 \mathrm{~kg} / \mathrm{ha}$ and Azotobacter+PSB (5 kg/ha) two weeks after transplanting of bulbs. Neem cake, Groundnut cake and $50 \% \mathrm{~N}$ in $\left(\mathrm{T}_{3}\right)$ were applied as top dressings on 45 DAP. Foliar spray of $\mathrm{ZnSo}_{4}$ $0.5 \%$ in $\mathrm{T}_{3}$ was also sprayed on 45 DAP.

Twenty randomly selected plants in each plot were tagged for recording observations on growth and yield parameters such as plant height, number of leaves per plant, number of root plant, root length plant, number of bulblets/clump, bulb diameter, yield (kg/plot), yield (t/ha). These parameters where recorded at harvest (ie) during 90 DAP. The observations recorded were statistically analysed [5] and results are presented in table 1.

\section{RESULTS AND DISCUSSION}

All treatments exhibited significant differences among themselves. Treatments $T_{4}$ to $T_{7}$ with organic inputs gave better results when compared to farmer's practice ( $T_{1}$ and $\mathrm{T}_{2}$ ). Organic manure in the improvement of soil fertility and productivity, acknowledged for generations would have helped in the plant metabolic activity through the supply of important nutrients besides micronutrients in promoting the vigorous growth. The organic manures derived from biological sources like FYM, Vermicompost,
Poultry manure, Oil cakes, Panchakavya are thus effective in enriching the soil and supporting the activities of microbes [6].

Further, results reveal that incorporation of Poultry manure+Neem cake $\left(\mathrm{T}_{6}\right)$ and Poultry manure+Groundnut cake $\left(\mathrm{T}_{7}\right)$ along with Biofertilizer+Panchakavya $3 \%$ improved the yield significantly in order, though $\mathrm{T}_{3}$ was the best. The highest yield obtained by incorporating poultry litter collaborates with the previous findings [7]. Treatments $\mathrm{T}_{4}$ and $\mathrm{T}_{5}$ produced yield which were significantly on par. The improvement in number of leaves, plant height, bulb diameter in the respective treatments might be due to the availability of vital macro and micronutrients in Vermicompost. Shobha and Pappiah [8] also were of opinion that application of Vermicompost is very effective in yield improvement of onion.

Though $\mathrm{T}_{3}$ was best due to the quick release of nutrients from the optimum level of chemical fertilizers; the study can be concluded stating that growth and yield of cluster onion in the tried ideotype of Ariyalur District can be significantly improved due to incorporation of Poultry manure (o.6 t/ha), Neem cake (0.57 t/ha)+Azospirillum and Phosphobacteria each @ 2 $\mathrm{kg} / \mathrm{ha}+$ Panchakavya (3\%). Repeated usage of such inputs over a few years would establish the merits of using organic nutrients in terms of sustainability; since the yield differences between $\mathrm{T}_{6}$ and $\mathrm{T}_{3}$ amounts to less than 5 per cent.

Table 1: Growth, yield and quality parameters of aggregatum onion at harvest

\begin{tabular}{|c|c|c|c|c|c|c|c|c|}
\hline Treatment & $\begin{array}{l}\text { Plant } \\
\text { height } \\
\text { (cm) }\end{array}$ & $\begin{array}{l}\text { No of } \\
\text { leaves/plant } \\
\text { (Nos) }\end{array}$ & $\begin{array}{l}\text { Number of } \\
\text { roots/plant } \\
\text { (Nos) }\end{array}$ & $\begin{array}{l}\text { Root } \\
\text { length } \\
\text { (cm) }\end{array}$ & $\begin{array}{l}\text { Bulb } \\
\text { diameter } \\
\text { (cm) }\end{array}$ & $\begin{array}{l}\text { Number of } \\
\text { bulblets/clump } \\
\text { (Nos) }\end{array}$ & $\begin{array}{l}\text { Yield } \\
\text { Kg/Plot }\end{array}$ & $\begin{array}{l}\text { Yield } \\
\text { (t/ha) }\end{array}$ \\
\hline $\begin{array}{l}\mathrm{T}_{1} \text {-FYM } 25 \mathrm{t} / \text { ha-Farmer } \\
\text { practice } 1\end{array}$ & 40.87 & 30.93 & 30.33 & 2.13 & 5.77 & 3.67 & 1.10 & 5.5 \\
\hline $\begin{array}{l}\mathrm{T}_{2}-\mathrm{FYM} 20 \\
\text { t/ha+Azotobacter+PSB- } \\
\text { Farmer practice } 2\end{array}$ & 41.47 & 32.23 & 33.00 & 2.27 & 7.08 & 4.30 & 1.43 & 7.16 \\
\hline $\begin{array}{l}\mathrm{T}_{3}-\mathrm{FYM} 2 \mathrm{O} \text { t/ha+NPK } \\
60: 60: 30 \\
\mathrm{~kg} / \mathrm{ha}+\mathrm{ZnSo} 4(0.5 \%)-\mathrm{Farmer} \\
\text { practice } 3\end{array}$ & 54.23 & 44.73 & $57 \cdot 33$ & 2.91 & 9.89 & 6.20 & 4.25 & 21.1 \\
\hline $\begin{array}{l}\mathrm{T}_{4} \text {-Vermicompost (1.8 t/ha), } \\
\text { Neem cake } \\
\text { (o.57t/ha)+Azospirillum and } \\
\text { Phospobacteria each @ } 2 \\
\text { kg/ha+Panchakavya ( } 3 \%)\end{array}$ & 43.93 & $37 \cdot 30$ & 40.33 & 2.52 & 7.85 & 4.73 & 2.43 & 11.8 \\
\hline $\begin{array}{l}\mathrm{T}_{5^{-}} \\
\text {Vermicompost(1.8t/ha),Gro } \\
\text { undnut cake } \\
\text { (o.57t/ha)+Azospirillum and } \\
\text { Phospobacteria each @ } 2 \\
\text { kg/ha+Panchakavya (3\%) }\end{array}$ & 42.80 & 34.67 & 36.00 & 2.43 & 7.29 & 4.43 & 1.87 & 9.3 \\
\hline $\begin{array}{l}\mathrm{T}_{6}-\text { Poultry manure (o.6 } \\
\mathrm{t} / \mathrm{ha}) \text {, Neem cake (0.57 } \\
\text { t/ha)+Azospirillum and } \\
\text { Phospobacteria each @ } 2 \\
\mathrm{~kg} / \mathrm{ha}+\text { Panchakavya ( } 3 \%)\end{array}$ & 50.30 & 39.97 & 48.33 & 2.77 & 8.71 & 5.47 & 3.65 & 17.6 \\
\hline $\begin{array}{l}\mathrm{T}_{7} \text {-Poultry manure (o.6t/ha), } \\
\text { Groundnut cake } \\
\text { (0.57t/ha)+Azospirillum and } \\
\text { Phospobacteria each @ } 2 \\
\mathrm{~kg} / \text { ha+Panchakavya ( } 3 \%)\end{array}$ & 47.13 & 38.70 & 43.00 & 2.68 & 8.27 & 4.90 & 2.73 & $13 \cdot 3$ \\
\hline S. Ed & 1.11 & 2.79 & 2.92 & 0.11 & 0.38 & 0.26 & 0.23 & 0.55 \\
\hline CD (0.05\%) & 2.42 & 6.08 & 6.37 & 0.25 & 0.84 & 0.57 & 0.50 & 1.20 \\
\hline
\end{tabular}




\section{REFERENCES}

1. Anonymous, 2010, Indian Horticulture data base, 2009, National Horticlture Board, Ministry of Agriculture, Government of India, Gurugaon, pp. 165166.

2. Shinde, M. N. and Sontake, M. B., 1993, Bulb crops. In: Vegetable Crops (Ed. T. K. Bose, M. G. Som and J. Kabir) revised edition. Naya Prakashan, Calcutta, pp. 641-685.

3. Aisha, A. H., F. A. Rizk, A. M. Shaheen and M. M. Abdel-Mouty, 2007. Onion plant growth, bulbs yield and its physical and chemical properties as affect by organic and natural fertilization. Res. J. Agric. Biol. Sci., 3:380-388.

4. Prabhakar, M., Hebbar, S. S. and Nair, A. K. 2012. Effect of organic farming practices on growth, yield and quality of rose onion (Allium cepa.). Indian Journal of Agricultural Sciences 82 : 500-03.

5. Panse, G. V. G. and Sukhatme, R. V. (1989). Statistical Methods for Agriculturral Workers, ICAR, New Delhi.

6. Kitturmath, M. S., Giradd, R. S. and Basavarj, B. (2007). Nutrient changes during earth warm, Eudriluse ugeneiae (Kingberg) mediated Vermicomposting of agro-industrial waste. Karnataka. J. Agric. Sci., 20:653-654.

7. Mousa, A. A. and Mohammed, M. F. (2009). Enhanced yield and quality of onion (Allium cepa L. cv. Giza 6) produced using organic fertilization. Ass. Univ. Bull Environ. Res., 12 : 9-19.

8. Shobha, N. and Pappiah, C. M. (2000). Nutritional studies in seed propagated aggregatum (small) onion. South Indian J. Hort., 48 (1/6): 105-107. 